\title{
Scanning Electron Microscopic Studies upon Daily Changes of the Endometrium of Earlier Stage of Attachment in Pregnant Swine
}

\author{
Yuitsu Yококı, Shohkichi Iwamura, Tadahiro Inoue \\ and Naotake Matsumoto* \\ National Institute of Animal Health, 1-1, Kannondai 3-chome, \\ Tsukuba-shi Ibaraki, 305 \\ *Gunma Animal Husbandry Experiment Station, 2425, Fujimi-mura, \\ Seta-gun, Gunma, 371-01
}

(Accepted for publication June 28, 1988)

\begin{abstract}
Summary. Morphological daily changes in the endometrium of the earlier stage of attachment from the pregnant swine were examined histologically using light and scanning electron microscopes (SEM). On the 7th day after mating (the stage of intrauterine migration), a wavy swelling made by pseudostratified epithelium was observed as islets by SEM. On the 11th day (the filamentous blastocyst stage), the wavy structures were disappeared and the surface of the epithelial cells was covered with numerous microvilli like a carpet. On the 13th or 14th day (the adhesion stage), the epithelial cells showed a marked dome-like protuberance. The microvilli were short and thick and decreased in number. On the 17th or 18th day (the early attachment stage), the apical protrusions of the individual epithelial cells revealed balloon-like structures and most of the microvilli were disappeared. The chorionic cells inserted their long microvilli into the intercellular space of the maternal epithelial cells. On the 22nd or 23rd day (the attachment stage), the epithelial cells became larger and the surfaces were densely covered with short microvilli again. KEY WORDS; SWINE, ENDOMETRIUM, SCANNING ELECTRON MICROSCOPY, EMBRYO, PREGNANCY.
\end{abstract}

Jpn J Anim Reprod 34, 182-190, 1988

\section{着床早期における豚子宮内膜の走查電子顕微鏡的観察}

\author{
横木 勇逸・岩村 祥吉 - 井上 忠恕 ·松本 尚武* \\ 農水省家畜衛生試験場，勇305 茨城県つくば市観音台 3-1-1 \\ *群馬県畜産試験場，371-02 群馬県勢多郡富士見村小暮 2425
}

誐の受精卵は，交配後 $5 \sim 6$ 日までは子宮角卵管端に 你化するが，その後，子宮内移送により両子宮角の全域 に及び，交配後11日頃から円形の肧盤胞が筒状から糸状 へと急速に伸長することが認められている (Dhindas and Dziuk, 1965; Anderson, 1978; Geisert et al., 1982)。 この時期までの子宮内膜は着床の準備期間であり，性周 期に伴う子宮内膜と妊娠子宮内膜との間に著しい違いは
みられない (Steinbach and Smidt, 1970; King et al. 1982 ; Stroband et al., 1986)。

子宮内膜が胀盤胞からの情報を受けて妊娠反応を示す 時期は，交配後12日前後とされている。この時期，妊娠 子宮は子宮への血流量や子宮内血管の透過性の增加拈よ び子宮内分泌の增加などが認められている (Zavy et al., 1980 ; Geisert et al., 1982; Keys et al., 1986)。また, 
Table 1. Number of corpora lutea and embryos recoverd from pregnant swine on 2-23 days after mating

\begin{tabular}{rccccl}
\hline No. & Breed & $\begin{array}{c}\text { Age in } \\
\text { month }\end{array}$ & $\begin{array}{c}\text { Days after } \\
\text { mating }\end{array}$ & $\begin{array}{c}\text { Embryos } \\
\text { Corpora lutea }\end{array}$ & $\begin{array}{c}\text { Shape } \\
\text { of conceptus }\end{array}$ \\
\hline 1 & W & 27 & $2 \sim 3$ & $18 / 20$ & spherical \\
2 & L & 18 & 6 & $6 / 9$ & spherical \\
3 & D & 26 & 7 & $10 / 16$ & spherical \\
4 & D & 19 & $8 \sim 9$ & $6 / 30$ & round vesicle \\
5 & L & 18 & 9 & $10 / 12$ & round vesicle \\
6 & L & - & $10 \sim 11$ & $17 / 19$ & round vesicle \\
7 & L & 20 & 11 & $14 / 17$ & tubular or filamentous \\
8 & D & 12 & 11 & $11 / 16$ & filamentous \\
9 & L & 21 & 12 & $8 / 16$ & filamentous \\
10 & D & 66 & 13 & $15 / 22$ & filamentous \\
11 & L & 15 & 14 & $10 / 11$ & filamentous \\
12 & L & 15 & $14 \sim 15$ & $9 / 10$ & filamentous \\
13 & D & 55 & 17 & $6 / 29$ & embryo \\
14 & D & - & 18 & $22 / 23$ & embryo \\
15 & W & 26 & $18 \sim 19$ & $14 / 16$ & embryo \\
16 & H & 13 & 20 & $12 / 18$ & embryo \\
17 & L & 36 & 22 & $17 / 19$ & embryo \\
18 & L & 22 & $22 \sim 23$ & $11 / 13$ & embryo \\
19 & LW & 28 & $22 \sim 23$ & $12 / 18$ & embryo \\
\hline & Average & & & $12 / 17.5$ & \\
\hline
\end{tabular}

W: Large White L: Landrace D: Duroc 交配後14日以降の着床開始に関連する子宮内膜の形態学 的変化は, 光学顕微鏡 (光顕) 観察においては, 内膜上 皮細胞の隆起とそれに続いて起こる内腔への突出性変化 として見られ，胚側の緁毛膜細胞は内愺上皮細胞の突出 を囲む鋳型として観察されている（King et al., 1982）。 透過電子顕微鏡 (TEM) 観察においては, 交配後20日で 内膜上皮細胞表面の微絨毛が胚側の絨毛膜細胞の微細な シワあるいは微絨毛の中に入り込んでいることが認めら れている (King et al., 1982; 山内, 1987)。しかし, 着床に伴う子宮内膜表面の微細構造の変化について観察 した報告は少ない。

著者らは，交配後の経日的な子宮内膜の変化の光顕的 観察と胚の付着〜密着, 着床に関連した各時期の子宮内 膜表面の微細構造の変化について走査電子顕微鏡 (SEM) により検討した。

\section{材料および方法}

供試豚は交配後 2 日から 23 日の間に剖検し, 子宮内の 検査により胚が正常に存在した19頭を用いた（Table 1)。 各雌豚の子宮組織は, 黄体数および子宮内から採集した 肧の数を算定したのち, 一側子宮角を 4 等分し, それぞ れの部位から採取した。
H: Hampshire LW: Landrace $\times$ Large white

SEM に用いた組織片は，グルタールアルデヒド $1 \%$ 溶液で18～20時間固定し，さらに，オスミウム $1 \%$ 溶液 で 2 時間固定した。その後, アルコール系列で脱水, 酢 酸イソアミルに置換し, 炭酸ガス臨界点乾燥後, イオン スパッタ法による金蒸着を行ったのち, SEM (JSM-35 型）を用い加速電圧 $15 \mathrm{KV}$ で観察を行った。また，光 顕に用いた組織は SEM 用に採取した隣接部位をブアン 液, $10 \%$ フルマリン液に固定し, パラフィン切片を作 製後, H-E 染色, PAS 反応を施し観察した。

\section{成 績}

\section{1. 交配後における子宮内膜の光学顕微鏡的変化}

交配後 5 6 日の子宮内膜上皮は高い円柱細胞 $(49.1 \mu \mathrm{m})$ が並列した単層円柱上皮として観察された（Fig. 1)。そ の後, 交配後 7 日頃より内膜上皮に多列形成が見られ, 表面は波状の形態を示した（Fig. 2)。この波状形態は交 配後11日，胚が系状に伸長する時期に一致して消失し， 内膜上皮は再び低い円柱細胞 (20-25 $\mu \mathrm{m})$ が並列した配 列状態に復した（Fig. 3)。

子宮内膜上皮細狍内に打ける核は, 交配後10日頃まで は細胞の基底部に位置するが，胚が伸長を開始する11日 頃から上皮細胞の中間部に移動を開始した。交配後13〜 

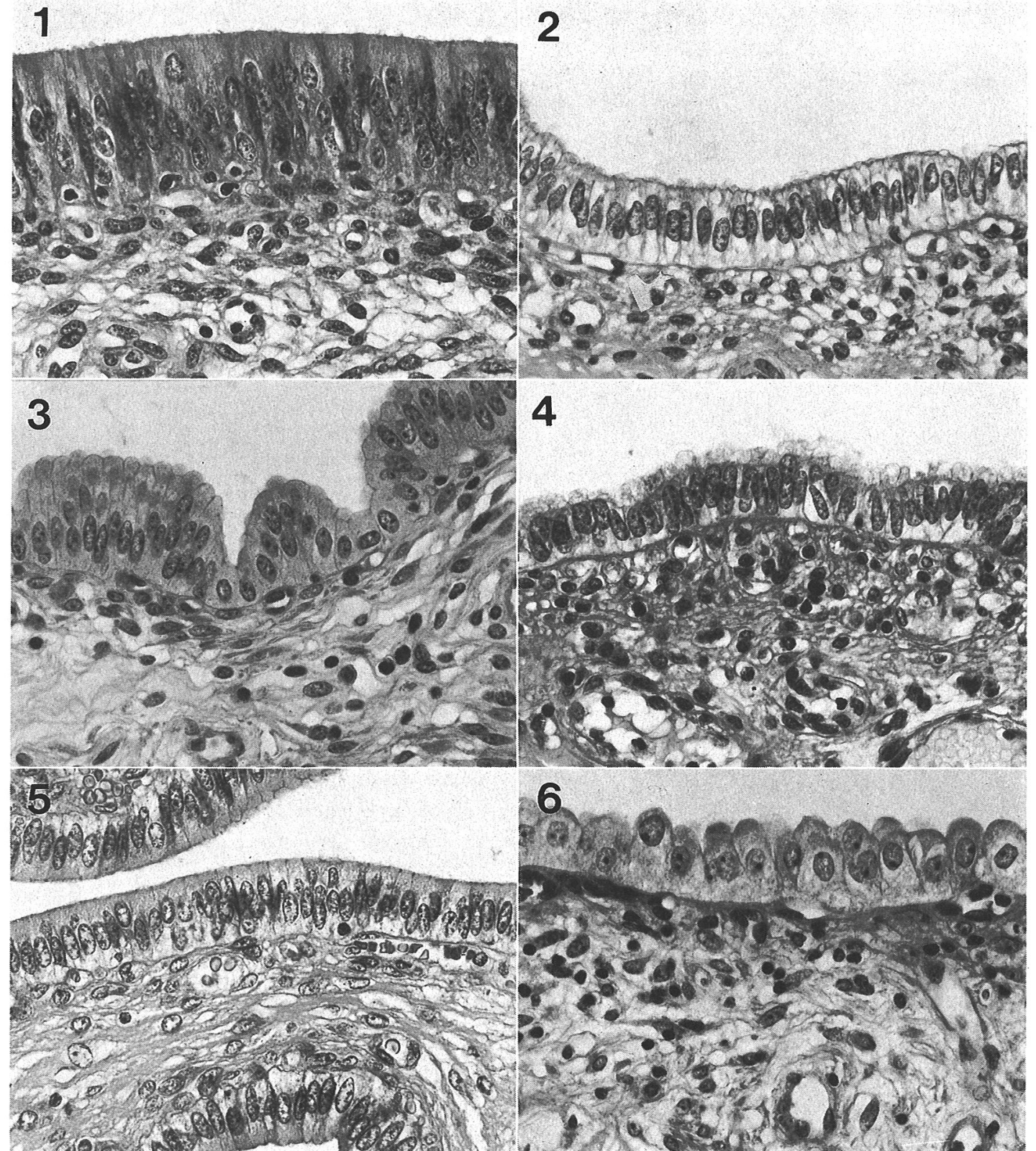

Figs. 1-6. Light microscopic observation on daily change of the endometrium. (Figs. 1-6, magnification $\times 400)$.

Fig. 1. On the 5 th or 6 th day after mating, the uterine epithelial cells were columnar in shape and had a smooth surface (No.2). Fig. 2. On the 7th day after mating. The uterine epithelium possessed wavy structures made by pseudostratified cells (No.3). Fig. 3. On the 10th or 11th day, the surface of the epithelium became smooth again, but the height of its component cells was shorter than that in Fig .1 (No.8). Fig. 4. Between 13th and 15th day, the epithelial cells bore centrally located or apical nuclei and pale cytoplasm (No.11). Fig. 5. On the 17th or 18 th day, there was a development of apical protrusion on the uterine epithelial surface (No. 13). Fig. 6. On the 22nd or 23rd day, epithelial cells had round apical profiles with large nuclei (No. 19). 


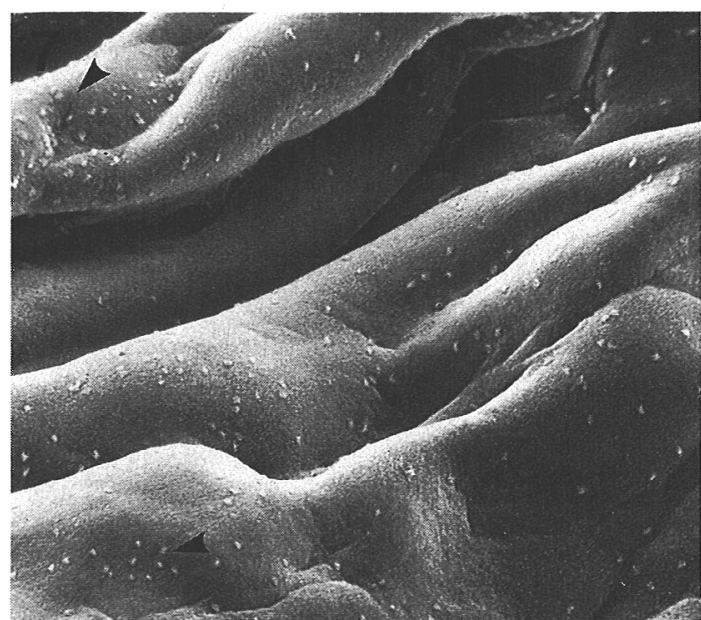

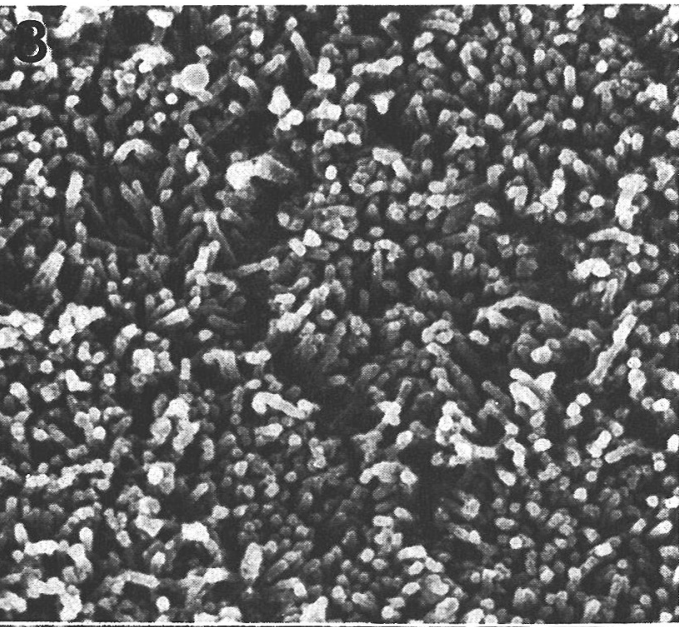
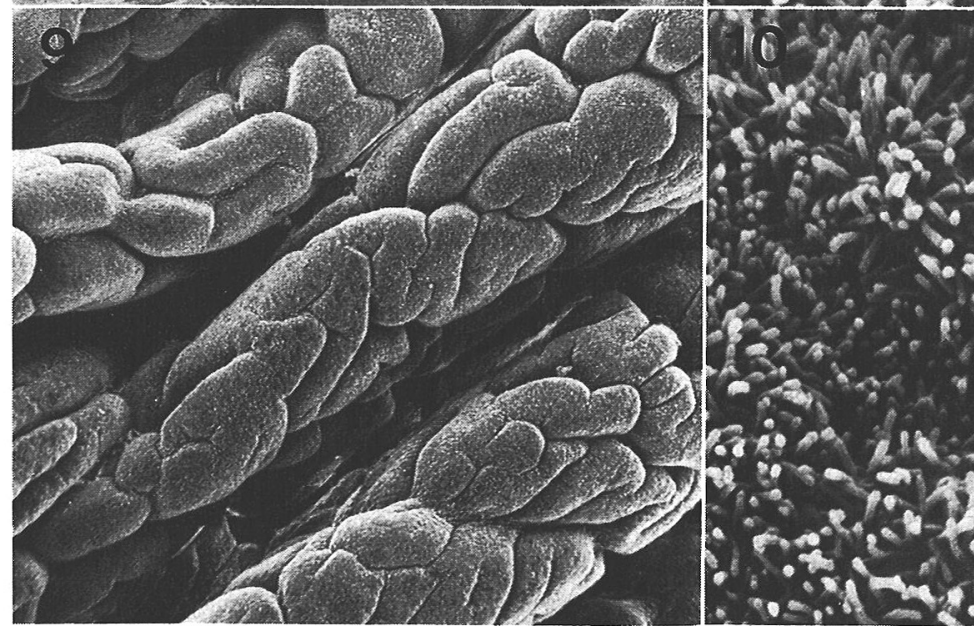

$\because x^{4}$,

$165 \cos$

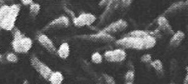

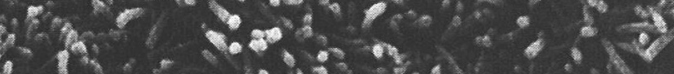

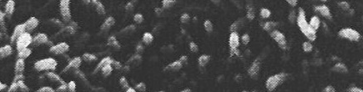

cris in: il

$\because 3-a^{3}=$

i $z^{2} z^{2}$ tras

$\because 7125.1702$

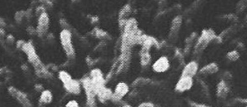

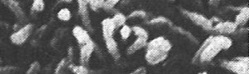

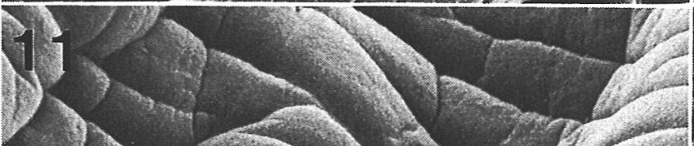

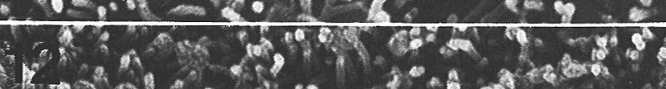

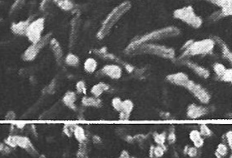
D.

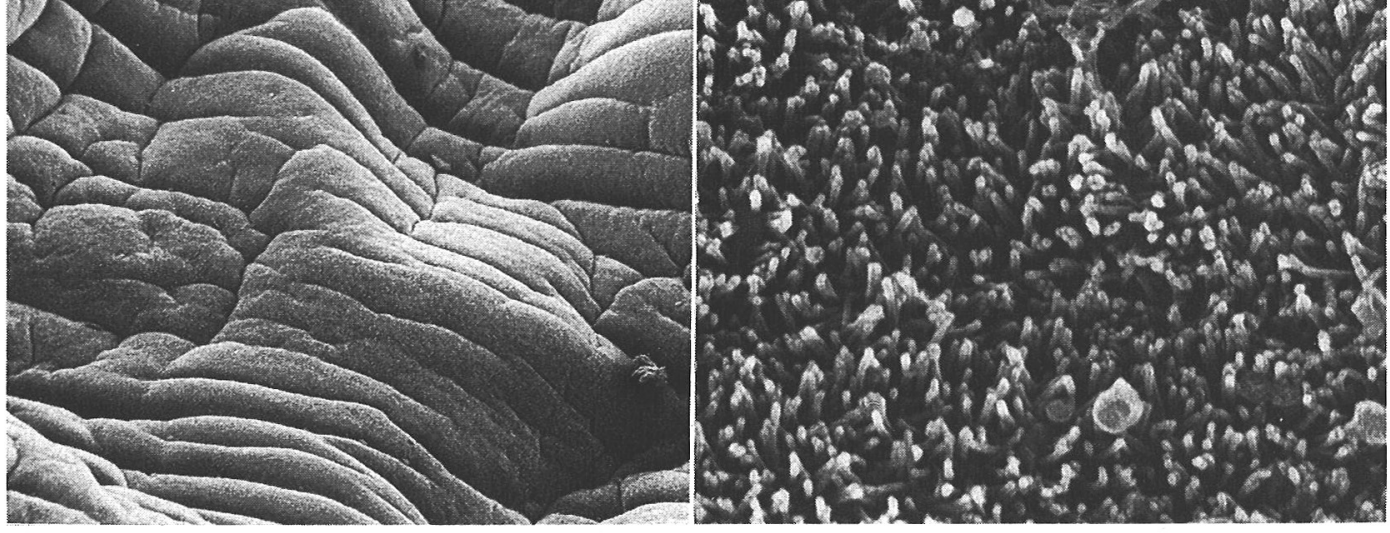




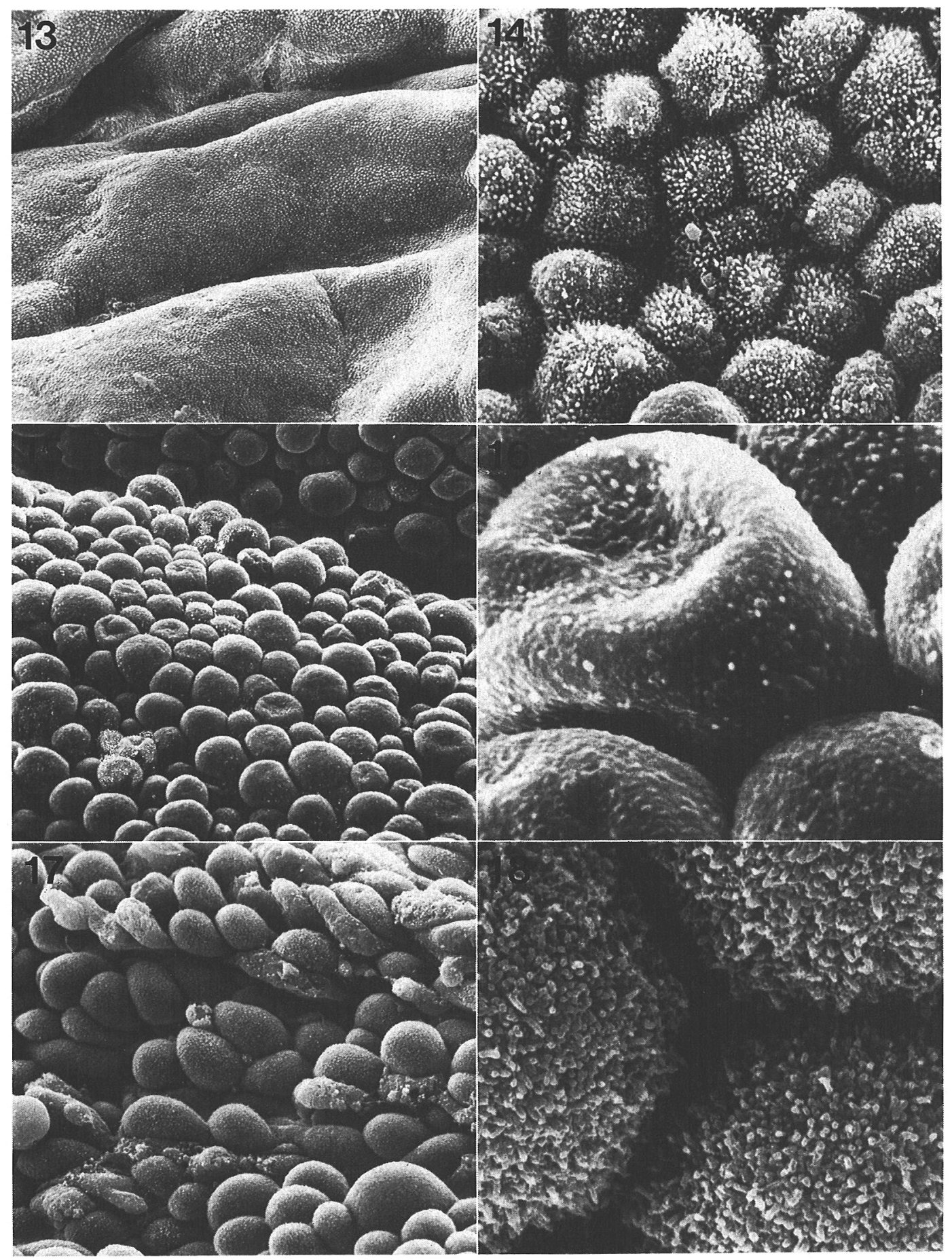




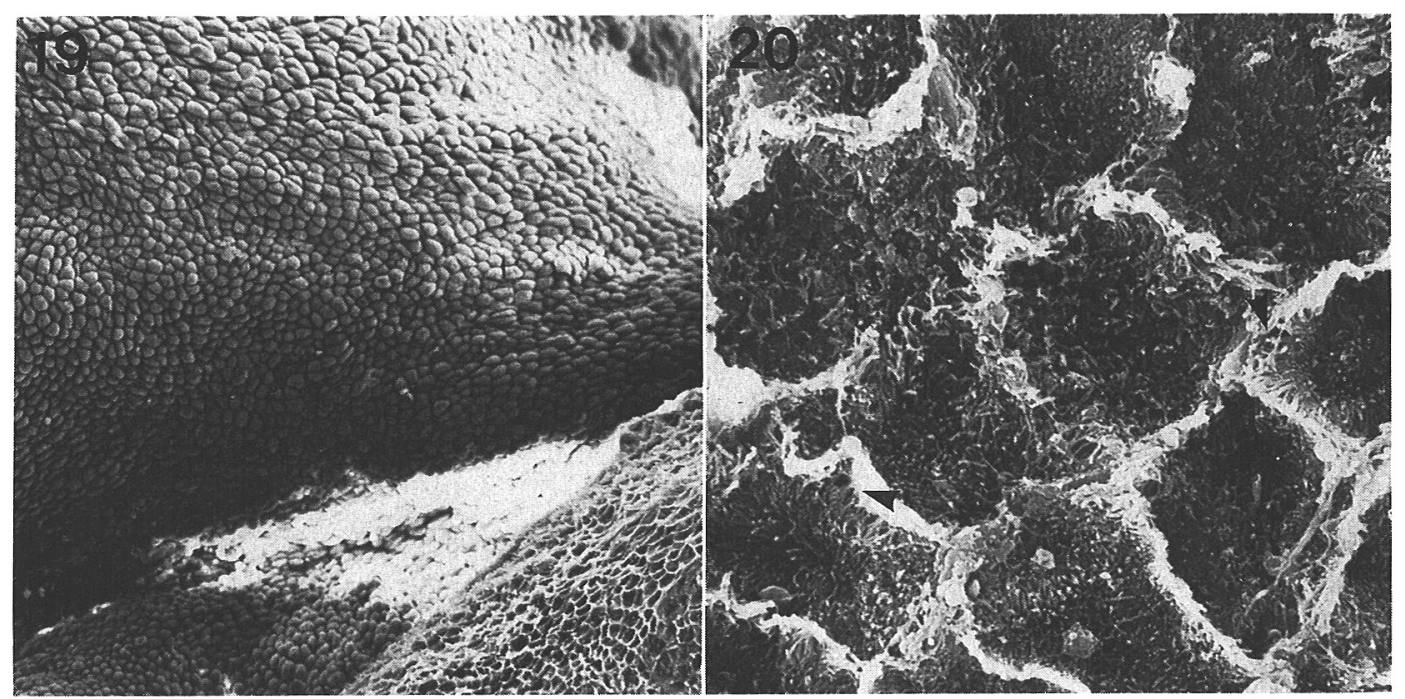

Figs. 7-19. Scanning electron microscopic observation on the daily change of the endom trium. Figs. 7 and 8. On the 5th or 6 th day after mating. The cell surface was flat and smooth with a few gland openings (arrows) and scattered ciliated cells (arrowheads) were also seen (Fig. 7 , $\times 100$ ). The surface was densely covered with microvilli of $1 \mu \mathrm{m}$ long (Fig. $8, \times 10,000)$. Figs. 9 and 10. On the 7 th day. The wavy structures observed by light microscopy comprised aggregates of irregular islands (Fig. 9, $\times 100$ ). The epithelial cell surface protruded like a button and the microvilli became slightly longer (Fig. 10, $\times 10,000$ ). Figs. 11 and 12. On th? 11 th day.

The island-like structures were disappeared (Fig. $11, \times 100$ ) and the cell surface was linsd by numerous microvilli like a carpet (Fig. 12, $\times 10,000$ ). Figs. 13 and 14. On the 13th or 14th day. The individual epithelial cells showed a dome-like protuberance (Fig. 13, $\times 1,000$ ) and the microvillie were shorter and thicker, and decreased in number (Fig. 14, $\times 10,000$ ). Figs. 15 and 16. On the 17th day. The individual cells revealed balloon-like structures (Fig. $15, \times 3,000)$ and most of the microvilli were disappeared (Fig. 16, $\times 10,000)$. Figs. 17 and 18.

On the 22nd or 23rd day. The epithelial cells became swelled (Fig. 17, $\times 3,000$ ) and short microvilli were seen on their surface again (Fig. 18, $\times 10,000)$. Figs. 19 and 20. On the 22nd or 23 rd day (attachment stage). This photograph shows the chorionic cells (lower right) which were stripped from the endometrial surface (Fig. 19, $\times 200$ ). The chorionic cells had short and long microvilli (arrows) and the latter were seen to have inserted into the intercellular space of the maternal cells (Fig. 20, $\times 3,000$ ).

15日，上皮細胞は極めて明るく，核は中間部からさらに 先端部へ移動した (Fig. 4)。その後, 上皮細胞の先端部 に突出がみられ (Fig. 5), 交配後22２3日の胚の着床部 位では細胞が大きくなり核も腫大した (Fig. 6)。

また，子宮腺の導管上皮細胞の高さも内膜上皮細胞の 高さの变化と一致し，交配後 $5 \sim 6$ 日で $29.4 \mu \mathrm{m}$ を示し たものが交配後10日前後で 22-24 $\mu \mathrm{m}$ となり，さらに交 配後17日以降では 14-16 $\mu \mathrm{m}$ と低くなった。子宮腺導管 の直径もこれらの変化と同様に交配後10日以降，次第に 小さくなり交配後17日では，筋層に近い部位の子宮腺と ほとんど同じ大きさを示した。

粘膜固有層に扒ける水董は，交配後12日ころから著明
となり，上皮細胞下に沶いて毛細血管の増加が見られ た。また，17〜18日以降のものに抢いて粘膜固有層にリ ンパ球の增加の認められた。

子宫腺上皮細胞のジスターゼ消化後の PAS 陽性反 応恔配後 7〜8 日頃出現し，11日頃から多くなり， 17日以降少なくなる傾向を示した。これらに対し, 子宮 内膜上皮細胞に沶いては，子宮腺上皮細胞より若干遅れ て交配後10日頃に出現し，14日で内膜上皮の全域で強い 反応が見られた。その後，17〜23日では着床部位を中心 に陽性反応を示した。

\section{2. 交配後における子宮内膜の走査電子顕微鏡的観察}

交配後 5 6 日：内膜上皮表面は比較的平坦で滑らか 
であり, 部位により線毛が散在していた。線毛はまれに 带状に集簇して見られるが，全体としては自験例の牛の 子宮に比較して少なかった。しかし, 子宮腺の開口部周 辺では線毛が比較的集簇して認められた (Fig. 7)。これ らの内膜上皮表面の桩大像では, 上皮細胞の輪郭が網目 状（Fig. 8）ないしは若干隆起したボタン状を呈し, $1 \mu \mathrm{m}$ 前後の短い微緁毛が密生していた。

交配後 $7 \sim 10$ 日: 光顕で認められた波状形態は盛り上 がった島状の構造を示す皺璧として観察された(Fig. 9)。 その上皮細胞表面は若干隆起したボタン状を示すものが 多い傾向にあり, ボタン状表面に見られた微䄉毛も若干 伸長していた（Fig. 10）。

交配後11日: 島状の構造は消失し内膜上皮表面は再び 平坦な構造を示す㮲襞となり，その上皮細胞表面には， 短い微䄉毛がジュウタン状に密生していた（Figs. 11, 12)。

交配後13〜14日：上皮細胞表面はドーム状の隆起を示 し, 微䋐毛は太く, 短くなり, 数も減少していた (Figs. $13,14)$ 。

交配後17 18日：上皮細胞表面はさらに突出しバルー ン状を示し, 微䄉毛は消失していた (Figs. 15，16)。胚 側の着床部位では䄉毛膜表面に伸長した微䄉毛がバルー ン状に突出した上皮細胞を包む様にして細胞の間隙に浅 く入り込んでいた。

交配後22２3日：子宮側着床部位の上皮細胞は一段と 大きくなり, 隆起した表面には再び短い微綫毛の密生が 見られた（Figs. 17，18）。一方, 肧側の微緁毛は子宮側 隆起表面の微絓毛との間に指状嵌合を示し, 上皮細胞の 周囲を包む微絨毛はさらに伸長して細胞間吵に深く入り 込んでいた（Figs. 19，20)。

\section{考察}

交配後 $2 \sim 10$ 日までの妊娠子宮内膜の光顕的変化は, これまでに明らかにされている性周期に伴う変化 (Steinbach and Smidt, 1970), とほぼ同じ傾向であるこ とを認めた。また，同様の成績は，Keys et al. (1986) や Stroband et al. (1986) によっても報告されて抢り, 父附後10日で胚が系状に伸長する以前の子宮内膜の変化 は, 胚の存否に関係なく進行する固有の変化と考えられ た。従って, 豚の受精卵（胚）移植には胚の発育とほぼ 一致した移植前の子宮内環境が必要であり, 同期化が要 求される理由の一つである。一方, 胚の側では円形胚盤 胞が系状に伸長する時期に，エストロゲンの合成および 分泌の高まることが知られており，このエストロゲン分
泌が子宮内膜に妊娠反応を起こし, 黄体機能の延長を図 るものと考えられている (Perry et al., 1976; Gadsby and Burton, 1980; Geisert et al., 1982)。また, Geisert et al.（1987）は，エストロゲン投与実験により性周期 延長の臨界期が発情開始後 9.5 日であることを認めて打 り,この時期以前の胚の死隇は性周期に影響しないもの と考えられた。

交配後 $7 \sim 8$ 日以降に，SEM で見られた子宮内膜上 皮の島状の構造は通常交配後11日ころ消失するが, この 形態は胚の子宮内移送開始時期に一致して現れること， 胚が子宮内分布を終えるとともに消失することなどか ら，肧の子宮内分布（移送）に関係した構造変化のよう に思われた。

子宮内膜に打ける最も早い生理学的な妊娠反応は, 交 配後11〜12日，胚が筒状あるいは系状に伸長を開始する 時期に認められる。この時期には, 子宮内回収液中にお けるエストロゲン值, プロスタグランジン值, 蛋白量, Ca などの増加 (Geisert et al., 1982) や, 子宮内の血流 量の增加 (Ford and Christenson, 1979), 子宮内膜の血 管の透過性の亢進 (Keys et al., 1986) などが示されて 打り，この時期に胚が子宮内膜への付着を開始すると考 えられている。一方, 形態学的には, 交配後11日頃から

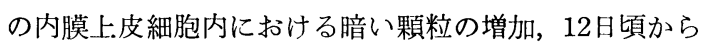
のグリコーグンの増加，11〜14日に水分を吸収した褧胞 の増加などが TEM により見られている (Stroband $e t$ $a l ., 1986$; 山内, 1987)。また, 光顕像では交配後14 16 日に扔いて内膜上皮細胞の先端部が突出する変化が認 められ (King et al., 1982), 肉眼的にも肧が子宮内膜 ヒダに沿って折りたたまれた状態で存在し, その部位で 軽度の充血の見られることが観察されている(Perry and Rowlands, 1962)。また, この時期着床と関連した免疫 反応と思われるリンパ球の増加も認められている。King et al., (1982) は，これらの胚打よび子宮に打ける生理 学的変化と形態学的変化との関連から着床周辺時期を胚 の付着 (12〜18日), 泼の密着 (13〜20日), 胚の着床 （17２4日）の 3つの時期にわけている。

今回の SEM による子宮内膜上皮表面の観察では, 交 配後11日（胚が筒状ないし糸状に伸長を開始する時期） では，性周期のものとの間に著明な形態的変化は認めら れない。しかし, 交配後13〜14日（泼の付着～密着時期） では, 内膜上皮細胞表面に打いて太く, 短い微綫毛を持 つ細胞表面のドーム状隆起の起こることが垫められた。 また, 交配後17〜18日（胚の着床開始時期）では, この ドーム状隆起はさらに突出し, 表面の微緁毛がほとんど 
消失したバルーン状の形態として観察される。この時期 に胚側では, 䄉毛膜表面の伸長した微絓毛がバルーン状 の内膜上皮細胞を包む状態で観察されることから，伸長 した微䄉毛が細胞間隙に入り込み子宮内膜との間に着床 の開始を図っているものと思われた。交配後20日以降の 胚の着床時期では，子宮側着床部位の上皮細胞は大きさ を增し，その表面には一度消失した微䋐毛が再び密生し ていた。これらは，胚側の微䋐毛との絡みで一層強固な 着床が起こるものと考えられた。これらの成績は, King et al.,（1982）が指摘した着床前後の胚の付着〜密着, 着床の時期を特徵的な内膜上皮表面の微細構造により明 らかに示したものである。

\section{謝辞}

ご校閲をいただいた当場研究第三部病理二研究室本間 惣太室長に深謝致します。また，本実験にあたってご協 力をいただいた当場研究第三部病理一研究室門田耕一技 官に深謝します。

\section{文献}

Anderson LL (1978) Growth, protein content and distribution of early pig embryos. Anat Rec 190: 143-154.

Dhindas DS, Dziuk PJ (1965) Time of embryonal migration in pigs with one ovary. J Anim Sci 24: 916.

Ford SP, Christenson RK (1979) Blood flow to uteri of sows during the estrous cycle and early pregnancy: local effect of conceptus on the uterine blood supply. Biol Reprod 21: 617-624.

Gadsby JE, Burton RD (1980) Oestrogen production by blastocyst and early embryonic tissues of vari- ous species. J Reprod Fert 60: 409-417.

Geisert RD, Renegar RH, Thatcher WW, Roberts RM, Bazer FW (1982) Establishment of pregnancy in the pig: I. Interrelationships between preimplantation development of the pig blastocyst and uterine endometrial secretions. Biol Reprod 27: 925-939.

Geisert RD, Zavy MT, Wettemann RP, Biggers BG (1987) Length of pseudopregnancy and pattern of uterine protein release as influenced by time and duration of oestrogen administration in the pig. J Reprod Fert 79: 163-172.

Keys JL, King GJ, Kennedy TG (1986) Increased uterine vascular permeability at the time of embryonic attachment in the pig. Biol Reprod 34: $405-411$.

King GJ, Atkinson BA, Robertson HA (1982) Implantation and early placentation in domestic ungulates. J Reprod Fert Suppl 31: 17-30.

Perry JS, Rowlands IW (1962) Early pregnancy in the pig. J Reprod Fert 4: 175-188.

Perry JS, Heap RB, Burton RD, Gadsby JE (1976) Endocrinolgoy of the blastocyst and its role in the establishment of pregnancy. J Reprod Fert Suppl 25: $85-104$.

Steinbach J, Smidt D (1970) Cyclical phenomena in the female genital tract of swine -Histological observations. J Anim Sci 30: 573-577.

Stroband HWJ, Taverne N, Langenfeld K, Barends PMG (1986) The ultrastructure of the uterine epithelium of the pig during the estrous cycle and early pregnancy. Cell Tissue Res 246: 81-89.

Yamauchi S (1987) Comparative morphology of the placentation. The Cell 19: 55-61 (in Japanese).

Zavy MT, Bazer FW, Thatcher WW, Wilcox CJ (1980) A study of prostaglandin $\mathrm{F}_{\alpha}$ as the luteolysin in uterine flushing from pregnant and nonpregnant gilts. Prostaglandins 20: 837-851. 
着床早期に打ける豚子宮内膜の経日的変化について光顕および走查電顕で観察し, 肧の付着〜密着, 胚の着床時における子宮内膜上皮の細胞表面微細構造の変化を走查電顕により明らかにした。

交配後 7 日 (胚の移送時期), 子宮内膜のヒダ表面に見られた上皮細胞の多列性形成は盛り上がった 波状形態を示し, 島状の構造として観察された。

交配後11日(肧が系状に伸長する時期)，内膜上皮は，島状の形態が消失して平坦となり，その上皮 細胞表面に微䄉毛がジュウタン状に密生していた。

交配後13〜14日 (胚が子宮内膜に付着〜密着する時期)，子宮内膜上皮細胞表面はドーム状に隆起す る著明な反応を示し，その表面の微絨毛は太く，短くなり，また，数も減少していた。

交配後17 18日 (胚が子宮内膜に着床を開始する時期)，光顕で観察された内膜上皮表面の突出は走 查電顕像では内腔に著しく突出したバルーン状の形態を示し，その表面の微絓毛はほとんど消失して いた。一方, 肧側の着床部位では絨毛膜表面に微䄉毛が伸長密生し，バルーン状に突出した内膜上皮 細胞を包むようにして細胞間隙に入り込んでいた。

交配後22〜23日 (胚の着床時期), 䄉毛膜側の微絨毛に包まれた着床部位の内膜上皮細胞は一段と大 きくなり，その隆起表面には再び短い微䄉毛の再生がみられた。 